Maurice A. Deane School of Law at Hofstra University Scholarly Commons at Hofstra Law

Hofstra Law Faculty Scholarship

2003

\title{
The Sentences That Bind (The States)
}

James Sample

Maurice A. Deane School of Law at Hofstra University

Follow this and additional works at: https://scholarlycommons.law.hofstra.edu/faculty_scholarship

\section{Recommended Citation}

James Sample, The Sentences That Bind (The States), 103 Colum. L. Rev. 969 (2003)

Available at: https://scholarlycommons.law.hofstra.edu/faculty_scholarship/498

This Article is brought to you for free and open access by Scholarly Commons at Hofstra Law. It has been accepted for inclusion in Hofstra Law Faculty Scholarship by an authorized administrator of Scholarly Commons at Hofstra Law. For more information, please contact lawcls@hofstra.edu. 


\title{
THE SENTENCES THAT BIND (THE STATES)
}

\author{
James J. Sample
}

In certain circumstances, federal district court judges impose criminal sentences that are required to be consecutive to yet-to-be-imposed state criminal sentences, including those state sentences that may, in fact, never be imposed. The federal courts of appeals are divided as to whether such sentences are statutorily authorized under the applicable provision, 18 U.S.C. \$3584(a). This Note argues that the sentences are not authorized under the statute, and further, that the sentences infringe on states' and defendants' rights.

\section{INTRODUCTION}

"The law governing prisoners subject to multiple sentences, particularly prisoners subject to multiple state and federal sentences, is hardly a model of clarity."1

The federal courts of appeals are divided as to whether federal district court judges may require the criminal sentences that they impose to be served consecutively to state sentences that have yet to be imposed. Though the split primarily turns on statutory interpretation, the controversy also unquestionably implicates defendants' rights as well as the boundaries of state sovereignty within the U.S. system of federalism. The issue arises when a defendant is convicted of a federal crime and sentencing for that federal conviction precedes either trial or sentencing on a state charge. The Second, Fifth, Eighth, Tenth, and Eleventh Circuits have concluded that district courts may require consecutive treatment, while the Sixth, Seventh, and Ninth Circuits have concluded that district courts may not. This Note argues that constitutional principles of dual sovereignty and traditional canons of statutory interpretation militate in favor of the minority's restrictive approach. ${ }^{2}$

1. McCarthy v. Doe, 146 F.3d 118, 120 (2d Cir. 1998).

2. The Second Circuit's status on this question resists simple classification. For the purpose of clarity, this Note classifies the Second Circuit as being in the majority as a result of its ruling in Salley v. United States, 786 F.2d 546 (2d Cir. 1986), but this classification is not entirely accurate, and is subject to the significant caveat that Salley preceded the enactment of the central applicable statutory provision, 18 U.S.C $\$ 3584$ (a) (2000). 1n addition, the Second Circuit's McCarthy decision actually agrees with the statutory analysis of the circuits in the minority, though the case technically decides a different question than that addressed in this Note. See McCarthy, 146 F.3d at 121-22 (2d Cir. 1998); infra note 74 and accompanying text.

The circuits are referred to as being in the "majority" or the "minority" in this Note due to the fact that the clear majority of the circuits that have addressed the underlying question have answered it in the affirmative. This is true regardless of the categorization of the Second Circuit, or the categorization of the Seventh Circuit, which takes the minority view on the central statutory question but takes an altogether different approach to the controversy. See Romandine v. United States, 206 F.3d 731 (7th Cir. 2000) (Easterbrook, 
The federal statute governing multiple sentences of imprisonment is 18 U.S.C. $\$ 3584(\mathrm{a}) .^{3}$ It states:

If multiple terms of imprisonment are imposed on a defendant at the same time, or if a term of imprisonment is imposed on a defendant who is already subject to an undischarged term of imprisonment, the terms may run concurrently or consecutively, except that the terms may not run consecutively for an attempt and for another offense that was the sole objective of the attempt. Multiple terms of imprisonment imposed at the same time run concurrently unless the court orders or the statute mandates that the terms are to run consecutively. Multiple terms of imprisonment imposed at different times run consecutively unless the court orders that the terms are to run concurrently. ${ }^{4}$

The circuit split exists in large part because $\$ 3584$ (a) does not explicitly account for the sentencing dilemma addressed by this Note, i.e., whether federal district judges may impose sentences that are required to be consecutive to state sentences that have not yet been imposed. At the most basic level, the split revolves around the correct interpretation of the phrase "[m]ultiple terms of imprisonment imposed at different times." The circuits in the majority interpret this phrase as including state prison sentences that have not yet been imposed at the time of the federal sentencing. The circuits in the minority, however, do not. They construe the second and third sentences of the section (in which that language appears) to apply only to situations clescribed in the statute's first sentence-those where a federal defendant is either facing "multiple terms of imprisonment . . . imposed . . . at the same time," or is "already subject to an undischarged term of imprisonment."; Under this restrictive reading, the last two sentences of the section are thus dependent on the existence of the circumstances denoted in the section's first sentence in order to have an operative effect.

The Note consists of two major Parts. Part I explains the split among the circuits. Within each camp, the justifications for the respective positions vary widely, and in some cases, the decisions can only be understood in light of their complex factual and procedural idiosyncrasies. The underlying complexities of the cases have produced confusion both within

1.); infra Part II.C. Put differently, platusible arguments exist that the split is not five-tothree as this Note claims, but actually four-to-three (with the Second Circuit not included at all); five-two-one (with the Seventh Circuit's unique approach considered separately); or four-two-one (combining the variables in the two previous categorizations).

3. 18 U.S.C. $\$ 3584(\mathrm{a})$.

4. Id. Part of the Comprehensive Crime Control Act of 1984, $\$ 3584$ (a) became effective on November 1, 1987. Pub. L. No. 98-473, 98 Stat. 2000 (codified at 18 U.S.C. $\$ 3584(2000))$.

5. 18 U.S.C. $\$ 3584(\mathrm{a})$.

6. Id. See infla Part I1.A, detailing the analytical steps underlying the minority's restrictive approach. 
and among the circuits. That confusion underscores the need for the split to be resolved.

Part II concludes that the circuits in the minority are correct: Federal judges do not have the power to require that their sentences be served consecutively to state sentences that have not yet been imposed. The Note contends that this conclusion holds up when subjected to textualism, to approaches employing traditional canons of interpretation, to considerations of federal-state comity, and to approaches utilizing legislative history for interpretive guidance.

Part II also addresses the non-statutory policy and administrative considerations relevant to the controversy, paying particular attention to Judge Frank Easterbrook's opinion for the Seventh Circuit in Romandine v. United States. ${ }^{7}$ Although he agrees with the statutory interpretation of the circuits opposed to the consecutive sentences at issue, Judge Easterbrook ultimately concludes in Romandine that the conflict among the circuits is "illusory." holding is correct-the consecutive sentences at issue are beyond the scope of a district court's powers-Judge Easterbrook's conclusion that the split is "illusory" decidedly is not.

\section{Exposition of the Circuit Split}

\section{A. Developments Prior to the Enactment of $\$ 3584(a)$}

The question considered in this Note has been addressed by eight federal courts of appeals. ${ }^{9}$ Before discussing their varying interpretations of $\S 3584(\mathrm{a})$, it is instructive to examine the first two appellate opinions that addressed the issue prior to the effective date of $\$ 3584(\mathrm{a})$. The Ninth and Second Circuits each considered the wisdom of the sentences at issue before the imposition of $\$ 3584$ (a), and the conflicting reasoning in their opinions highlights early tensions that have only been exacerbated by the statute itself.

The Ninth Circuit's decision in United States v. Eastman, ${ }^{10}$ the first federal appellate court opinion to address the issue, placed significant emphasis on the concerns of federal-state comity that still affect the inquiry today. Gerald Eastman had been convicted in California of a state

7. 206 F.3d at 731.

8. Id. at 738 .

9. For the decisions most comprehensively analyzing the central question addressed by this Note, see United States v. Sumlin, 317 F.3d 780 (8th Cir. 2003); Taylor v. Sawyer, 284 F.3d 1143 (9th Cir. 2002); United States v. Mayotte, 249 F.3d 797 (8th Cir. 2001); Romandine, 206 F.3d at 731; United States v. Quintero, 157 F.3d 1038 (6th Cir. 1998); McCarthy v. Doe, 146 F.3d 118 (2d Cir. 1998); United States v. Williams, 46 F.3d 57 (10th Cir. 1995); United States v. Ballard, 6 F.3d 1502 (11th Cir. 1993); United States v. Clayton, 927 F.2d 491 (9th Cir. 1991); United States v. Brown, 920 F.2d 1212 (5th Cir. 1991); Salley v. United States, 786 F.2d 546 (2d Cir. 1986); United States v. Eastman, 758 F.2d 1315 (9th Cir. 1985).

10. 758 F.2d at 1315 . 
crime but had not been sentenced by the state court when he was sentenced in federal district court for a variety of fraudulent monetary transactions. The pertinent portion of the federal sentence imposed read as follows: "1t is ordered that the sentence is to run consecutive to any sentence that the defendant receives from the State of California." 1 The sentence conflicted with a California law that expressly granted California state judges the discretion to prescribe that their sentences were to run either concurrently with, or consecutive to, pre-existing sentences. ${ }^{12}$

The Ninth Circuit concluded that the district court's sentence, "if given effect, would preempt the right of the state to apply its own laws on sentencing for violation of state criminal laws," 13 and that upholding the sentence would have "deprived [Eastman] of the benefit of the liberal California law in that he would [have lost] his chance to have the state sentence run concurrently with his federal sentence." 14 The court noted that in addition to depriving Eastman of his rights under California state law, the imposition of the sentence would have "create[d] uncertainty and ambiguity," possibly engendering future difficulties in the calculation of his federal sentence, and thus depriving him of his federal right to "a clear, unambiguous sentence."15

The Second Circuit took a radically different approach in Salley $v$. United States. ${ }^{16}$ Robert Salley was arrested in May 1981 on federal charges of possession of stolen treasury checks and was released on his own recognizance. He was subsequently arrested on New York state charges of robbery and incarcerated in a state facility awaiting trial. While in state custody, but before the state charges were resolved, Salley was sentenced in the Eastern District of New York to a prison term of four years and nine months. The sentence was "to run consecutively to whatever sentence Salley received in connection with his pending New York robbery charge." 17 Approximately eight months after his federal sentencing, Salley pled guilty to the state charge and "was sentenced to a term of one and one-half to four and one-half years, to run concurrently with the previously imposed federal sentence." 18 Salley thus requested a transfer from state custody into federal custody so that the sentences could run concurrently per the state court's direction. In accordance with the federal order for a consecutive sentence, however, Salley was not transferred to federal custody until his state sentence was completed, and the calculation of time served on his federal sentence did not commence until the transfer occurred. ${ }^{19}$

11. 1d. at 1317.

12. Id.; Cal. Penal Code $\$ 669$ (West 1999).

13. 758 F.2d at 1318 .

14. Id.

15. Id.

16. 786 F.2d 546 (2d Cir. 1986).

17. Id. at 547 .

18. Id. (emphasis added).

19. Id. 
Faced with the conflicting sentences, the Second Circuit first noted the frequently recognized power of federal judges to impose sentences that were required to run consecutively to existing state sentences. ${ }^{20}$ Second, the court interpreted three decisions-Anderson $v$. United States, ${ }^{21}$ Farley $v$. Nelson, ${ }^{22}$ and Casias $v$. United States ${ }^{23}$-as articulating the principle that federal judges could impose consecutive sentences "regardless of whether the state sentence [had] as yet been imposed." 24 The one appellate court that had addressed the question at issue prior to Salley was the Ninth Circuit, in Eastman, ${ }^{25}$ but the Salley court declined to follow the decision and attempted to distinguish it based on the sequence of events that followed the imposition of the sentence. ${ }^{26}$

In subsequent decisions, the majority opinion in Salley has received far less attention than Judge Jon Newman's concurrence. Judge Newman concurred in the Salley result on procedural grounds, ${ }^{27}$ but he nevertheless criticized the court's interpretation of the three decisions empha-

20. Id. (citing Hayden v. Warden, I24 F.2d 514, 514-I5 (9th Cir. 1941); United States ex reI. Lombardo v. McDonneII, I53 F.2d 919, 922 (7th Cir. 1946); Lavoie v. United States, 310 F.2d 117, 117-I8 (1st Cir. 1962); Anderson v. United States, 405 F.2d 492, 493 (10th Cir. 1969); United States v. Lee, 500 F.2d 586, 587-88 (8th Cir. 1974)).

21. 405 F.2d 492 (10th Cir. 1969).

22. 469 F. Supp. 796 (D. Conn. 1979), aff'd mem., 607 F.2d 995 (2d Cir. 1979).

23. 421 F.2d 1233 (10th Cir. 1970).

24. Salley, 786 F.2d at 547.

25. 758 F.2d 1315 (9th Cir. 1985).

26. Eastman was clearly not binding precedent in the Second Circuit, but the Salley court's cursory attempt to distinguish Eastman is indicative of the confusion this issue created even prior to the enactment of $\$ 3584(\mathrm{a})$ :

To the extent that United States $v$. Eastman enunciates a different rule, it is dictum with which we disagree. In that case, after the defendant was sentenced in federal court, he was "taken by the United States Marshal to the place designated by the Attorney General for service of his federal sentence." In the instant case, Salley was remanded to the Metropolitan Correction Center [a federal facility] and was transferred several days Iater to State custody at Rikers Island.

Salley, 786 F.2d at 548 (citations omitted).

Judge Newman's criticism of the Salley majority's opinion casts doubt on the sufficiency of its analysis if not on its ultimate conclusion:

The only court to rule on the issue directly has held that a federal judge may not impose a sentence to run consecutively to a sentence that will be imposed in the future by a state court. It is not evident why the majority characterizes [the Eastman] holding as a dictum. [Eastman], appealing from denial of a motion pursuant to Fed. R. Crim. P. 35, challenged his federal sentence solely on the ground that it was consecutive to a state sentence not yet imposed. On appeal, he prevailed. The Ninth Circuit ruled that the consecutive feature of the sentence was invalid and remanded for resentencing.

Salley, 786 F.2d at 548-49 (Newman, J., concurring) (citations omitted).

Unfortunately, because $\$ 3584$ (a) does not clearly provide guidance with respect to the controversial sentences, the division that existed prior to the statute's enactment has only been aggravated.

27. Salley, 786 F.2d at 549 (Newman, J., concurring) (stating that Salley failed to enter a timely challenge to the consecutive aspect of the sentence "when the federal sentence was imposed"). 
sized by the majority in support of its result. ${ }^{28}$ Judge Newman wrote "separately to express . . . respectful disagreement with the view that a sentencing judge has authority to impose a sentence to run consecutively to a sentence that has not yet been imposed." 29 This disagreement was grounded in policy considerations similar to those expressed today by the courts adopting the minority's restrictive approach. Judge Newman emphasized that the "strong medicine" of a consecutive sentence "should be used only after awareness of a sentence already imposed so that the punitive effect of the consecutive sentence is carefully considered at the time of its imposition." ${ }^{30}$ In Judge Newman's opinion-and in the contemporary opinions of many of those opposed to the sentences at issue-one of the central problems that such sentences pose is that judges who impose them must attempt to weigh the unknown and unknowable in determining the appropriate sentence:

[t]he length of a primary sentence is always relevant to a reasoned decision concerning both the length of a consecutive sentence and the choice of imposing it consecutively. When the District Judge ... . decided to impose the [fifty-seven month sentence] consecutively, he had no idea of the length of the New York sentence to which those 57 months would be consecutive. ${ }^{31}$

28. Judge Newman acknowledged that the Anderson court "expressed its approval" of the sentences in question but noted that it "gave no reason for its approval." Id. Moreover, unlike in Eastman, the Anderson appellant "was not appealing from the imposition of [a] consecutive sentence," and the Anderson holding "was the unexceptional one that a federal sentence begins to run from the date a defendant is delivered to federal custody to begin serving his sentence." Id. In Judge Newman's view, the Farley holding was the same as that in Anderson, but "[u]nlike Anderson, Farley does not even contain a statement approving a sentence consecutive to a future sentence." Id. Finally, Judge Newman noted that the Casias decision dealt with a "state sentence imposed consecutively to [a] prexionsly imposed federal sentence." ld.

The particular nuances of the three cases cited by the Salley majority are beyond the scope of this Note as the cases have had almost no influence on any post $-\$ 3584$ (a) decision. However, the dearth of citations to the three cases, or to the Salley reasoning in general, especially compared to the influence of Judge Newman's concurrence, seems on balance to reflect a view that even those courts that have subsequently favored the consecutive sentences at issue have substantially favored ludge Newman's interpretations.

29. Id.

30. Id.

31. Id.; see also United States v. Quintero, 157 F.3d 1038, 1041 (6th Cir. 1998). The Quintero court noted that a range of logistical considerations not referenced by the statute would be necessary to accommodate the sentences at issue:

[A] llowing a district court to order a sentence to be served consecutively to a not yet imposed state sentence would create situations not contemplated by the statute. Consider the following example. A defendant is out on bail awaiting his state trial. He is tried and convicted of a federal crime. The district court orders that his sentence is to run consecutively to a not yet imposed state sentence and he is taken into federal custody and his sentence begins. Later, the state sentences the defendant. To give effect to the federal sentence, the Bureau of Prisons or the Attomey General would have to transfer the defendant to state custody to serve his state sentence, then receive the defendant back to complete 
Accordingly, Judge Newman characterized the imposition of such sentences as a "partial abdication of sentencing authority" and as "violat[ions] of the principle that sentences must be definite and unambiguous." ${ }^{2}$ Judge Newman's reasoning continues to influence courts on both sides of the split today. Courts opposed to the consecutive sentences at issue ground their secondary, non-statutory arguments similarly, ${ }^{33}$ and perhaps more importantly, Judge Newman's reasoning represents a significant hurdle that courts favoring the sentences must attempt to clear. This Note argues that the circuits in the majority fall short in that endeavor.

\section{B. The Majority's Permissive Approach}

The Second, Fifth, Eighth, Tenth, and Eleventh Circuits have concluded that district court judges may impose sentences that are required to be consecutive to state sentences that have yet to be imposed. The single most important element in the jurisprudence of the circuits taking the majority position is their broad reading of the statutory language of $\S 3584(\mathrm{a})$.

The statutory reasoning employed by the majority is essentially a three-step process: (1) a federal sentence and a yet-to-be-imposed state sentence constitute "multiple terms of imprisonment imposed at different times" $;^{34}(2)$ the default rule in the statute is that sentences are consecutive "unless the court orders that the terms are to run concurrently"; ${ }^{35}$ and (3) if consecutive sentences are the default, then, in the absence of an express and specific prohibition on consecutive sentences, a district court judge surely has the discretion to order them explicitly. ${ }^{36}$

his federal sentence. Nothing in the statute inclicates that Congress Id.

contemplated this start, stop, and start again sentence.

32. Salley, 786 F.2d at 548 (Newman, J., concurring) (citing Bius v. United States, 286 F.2d 652, 653 (10th Cir. 196I), for the principle that sentences are required to be definite and unambiguous).

33. See supra note 31 and accompanying text (describing the Sixth Circuit's characterization of the logistical consequences of allowing the sentences at issue); United States v. Clayton, 927 F.2d 49I, 493 (9th Cir. 199I) (finding such sentences "prejudicial" in that they deprive a defendant of the "right to have a state court consider whether a state sentence should run concurrently with his federal sentence" and may "result in problems in calculation of service of his sentence") (quoting United States v. Eastman, 758 F.2d 1315,1318 (9th Cir. 1985)).

34. 18 U.S.C. $\$ 3584$ (a) (2000).

35. Id.

36. See, e.g., United States v. Williams, 46 F.3d 57, 59 (10th Cir. 1995). There the court stated:

The plain meaning of $[\S 3584(\mathrm{a})]$ is that multiple terms of imprisonment imposed at different times will normally run consecutively, unless the district court affirmatively orders that the terms be served concurrently. We find no language in section $\$ 3584$ (a) prohibiting a district court from ordering that a federal sentence be served consecutively to a state sentence that has not yet been imposed. 
As discussed earlier, however, the statute does not directly address the specific question of whether or not the sentences at issue may be imposed; in fact, the section makes no reference at all to state sentences. ${ }^{37}$ The courts taking the majority's permissive approach must therefore read the statute broadly in order to bring yet-to-be-imposed state sentences under the umbrella of the phrase "multiple terms of imprisonment" 38 and must interpret the final sentence of the section, in which that phrase appears, to be an independent source of authority that is not limited to the circumstances indicated in the section's first sentence.

According to the last sentence of $\$ 3584(\mathrm{a})$, "[m]ultiple terms of imprisonment imposed at different times run consecutively unless the court orders that the terms are to run concurrently." ${ }^{99}$ The circuits which permit the imposition of the sentences in question interpret this language as "empower[ing], even encourag[ing], district judges to give a consecutive sentence as a sentence necessarily imposed at a different time from a state sentence." 40 To demonstrate the approach more specifically, one must consider the nuances of the particular cases.

The Fifth Circuit, in United States v. Brown, was the first appellate court to address the question following the enactment of $\S 3584(\mathrm{a}) .^{41}$ Defendant Welton Brown was sentenced in federal court to 240 months of imprisonment on charges stemming from a bank robbery. Finding the defendant to be a "dangerous recidivist," 42 the district court judge stated: "I want the record to be clear that it is not my intention that this Court's sentence should or shall run concurrently with any state court sentence which might be imposed on the charges pending against him in state court." 43 When the defendant challenged this on appeal, the Fifth Circuit reasoned that the sentence should be upheld, because $\$ 3584$ (a) "indicate [s] that the discretion exercised by the district court when determining whether to impose concurrent or consecutive sentences may consider subsequent sentences anticipated, but not yet imposed, in sepa-

1d. (emphasis added) (internal citation omitted).

Similarly, in United States v. Mayotte, 249 F.3d 797, 799 (8th Cir. 2001), the court held:

Neither the statute nor the Guidelines directly address whether the district court may impose a federal sentence to be served consecutively to a yet-to-be-imposed state sentence. They certainly do not prohibit it, howvever, and suggestive of the contrary the statute cncourages consecutive sentences when prison terms are imposed at different times....

Id. (emphasis added).

37. 18 U.S.C. $\$ 3584(\mathrm{a})$.

38. Id.

39. Id.

40. United States v. Ballard, 6 F.3d 1502, 1506 (11th Cir. 1993).

41. 920 F.2d 1212 (5th Cir. 1991).

42. Id. at 1217 .

43. Id. at 1216 . 
rate state court proceedings." ${ }^{44}$ Of course, as previously discussed, the statute does not actually refer to "subsequent" sentences, "anticipated" sentences, or even to "state court proceedings." Despite this, the excerpt quoted above constitutes the Fifth Circuit's entire explanation of its statutory interpretation. ${ }^{45}$

The Eleventh Circuit's decision in United States v. Ballard may make the most powerful argument for the consecutive sentences at issue. ${ }^{46} \mathrm{De}$ fendant Timothy Ballard was incarcerated in a Mobile, Alabama jail awaiting trial on armed-robbery charges when he wrote a letter threatening to kill President Bush. Ballard's hope was that his patent act of criminality would lead federal authorities directly to him. Indeed, Ballard desired to be charged with the crime of threatening the life of the President, so that he would be sentenced in federal court. Ballard was specifically attempting to avoid having to serve time in the state prison, and he thus attempted to manipulate the system in order to be sentenced first in the federal system to a federal institution and second, to a concurrent state term allowing him to serve part of his state term in the federal facility. ${ }^{47}$ The federal trial judge found that under the circumstances:

Although the defendant has not yet been convicted in state court . . . the Court finds that his federal sentence should be consecutive to any he should receive in state court. Th[at] is, any sentence he receives from this Court shall not begin until he is released from state custody. A concurrent sentence would not serve as a deterrent or punishment, but as an incentive. ${ }^{48}$

44. Id. at 1217.

45. Peculiarly, the Broum court claimed that "[d]ecisions from the Second and Ninth Circuits bolster this conclusion," but cited for support United States v. Adeniyi, 912 F.2d 615, 618 (2d Cir. 1990) (validating federal sentences consecutive to state sentences previously imposed), and United States v. Burns, 894 F.2d 334, 337 (9th Cir. 1990) (upholding a federal sentence imposed consecutive to an unexpired state sentence). Brown, 920 F.2d at 1217 . The combination of the Brown court's opaque statutory analysis, and its peculiar claim that the preceding cases "bolster" its conclusion, make the case the most impenetrable among those in the circuit split. The power to impose federal sentences that are consecutive to existing state sentences was not at issue in that case, nor is it at issue in this Note. That such an opinion was the first appellate decision to address the question would prove to be unfortunate foreshadowing regardless of one's normative view on the central issue. In considering a related issue, a later panel of the Fifth Circuit characterized the Brown holding as follows: "Although the plain language of [\$3584(a)] suggests that the district court is without discretion to order that a federal term of imprisonment run concurrent [or consecutive] with a yet-to-be-imposed state sentence, we have found to the contrary." United States v. Hernandez, 234 F.3d 252, 256 (5th Cir. 2000) (citing Brown, 920 F.2d at I2I7).

46. 6 F.3d 1502 (11th Cir. 1993).

47. The letter Ballard wrote from jail, dated May I1, 1992, read as follows: "Dear Mr. President, I am going to kill you, I am going to send you a pipe bomb. Love, Tinnothy Ballard." Ballard had previously been in several fights in the state prison and acknowledged to Secret Service agents that he believed that he would be killed by his fellow inmates if he were sentenced to the state prison; therefore he specifically researched how to commit a federal crime in order to be sentenced to a federal facility. Id. at I503.

48. Id. at 1504 (quoting trial court's pre-sentence report). 
Ballard appealed the sentence on the ground that it violated principles of dual sovereignty, as it deprived the state court of the discretion to make his state sentence concurrent with his federal sentence. Unlike the Brown court, which reproduced $\$ 3584$ (a) in its entirety but did not cite any particular portion of it, but like the other circuits in the majority, the Ballard court emphasized the closing language of $\$ 3584(\mathrm{a}) .{ }^{49}$ It is illustrative of the majority's approach to note that at seven pages, the Ballard opinion is the longest circuit opinion to have approved of the controversial sentences. Despite its relatively detailed analysis, however, the opinion does not address the arguably limiting language at the beginning of $\S 3584$ (a) or the statute's legislative history. According to the reasoning in Ballarl, the phrase "[m] ultiple terms of imprisonment imposed at different times" encompasses state sentences that have yet to be imposed, and the inquiry should next focus on whether the district court judge properly considered the sentencing factors in 18 U.S.C. $\$ 3553(\mathrm{a}),{ }^{50}$ which include the applicable Sentencing Guidelines. ${ }^{51}$ After acknowledging that the Guidelines did not "address Ballard's exact situation," 52 the court analogized to the provisions concerning defendants already subject

49. Id. at 1505. The final sentence reads: "Multiple terms of imprisonment imposed at different times run consecutively unless the court orders that the terms are to run concurrently." 18 U.S.C. $\$ 3584$ (a) (2000).

50. Ballarl, 6 F.3d at 1505 (noting that a district court judge's "discretion in determining whether a consecutive or concurrent sentence is appropriate is tempered by the statutory requirement that the sentencing court consider the factors listed in 18 U.S.C. $\$ 3553($ a)"). Section 3553 (a) provides, in pertinent part, that courts determining which criminal sentences shoukd be imposed must consider:

(1) the nature and circumstances of the offense and the history and characteristics of the defendant;

(2) the need for the sentence imposed-

(A) to reflect the seriousness of the offense, to promote respect for the law, and to provide just punishment for the offense;

(B) to afford adequate deterrence to criminal conduct;

(C) to protect the public from further crimes of the defendant; and

(D) to provide the defendant with needed educational or vocational training, medical care, or other correctional treatment in the most effective manner;

(3) the kinds of sentences available;

(4) the kinds of sentence and the sentencing range established for-

(A) the applicable category of offense committed by the applicable category of defendant as set forth in the guidelines issued by the Sentencing Commission pursuant to [28 U.S.C. $\$ 994(\mathrm{a})(1)]$ and that are in effect on the date the defendant is sentenced; ...

(5) any pertinent policy statement issued by the Sentencing Commission pursuant to 28 U.S.C. $\$ 994$ (a) (2) that is in effect on the date the defendant is sentenced;

(6) the need to avoid unwarranted sentence disparities among defendants with similar records who have been found guilty of similar conduct; and

(7) the need to provide restitution to any victims of the offense.

18 U.S.C. $\$ 3553(\mathrm{a})$.

51. See 18 U.S.C. $\$ 3553(a)$.

52. Ballard, $6 \mathrm{~F} .3 \mathrm{~d}$ at 1505 . 
to an undischarged imprisonment term, ${ }^{53}$ and noted that the Guidelines "take a dim view of crimes committed while in custody for another offense and direct a separate sentence to punish the additional crime." 54 The Guidelines also favor the imposition of consecutive sentences " to the extent necessary to achieve a reasonable incremental punishment for the instant offense," $" 55$ and the Ballard court interpreted the combination of the statutory regime and the Guidelines to "evince a preference for consecutive sentences when imprisonment terms are imposed at different times." 56

Ballard is unique in that the defendant intended to be caught and sentenced for committing a crime in order to manipulate his sentence. Ballard's actions clearly carried the risk of increasing his jail time, as a subsequent state judge could impose a consecutive sentence, but the Eleventh Circuit found that such a "risk is apparently insufficient to deter persons like the defendant." 57 Due to this unusual circumstance, the court strongly desired that the defendant actually serve "separate" federal time as a result of the federal sentence. ${ }^{58}$ Since Ballard was facing a mandatory minimum sentence of ten years if convicted on the state charge, but only twenty-one months on the federal charge, the Eleventh Circuit found that serving the state sentence concurrently with the federal one would effectively "negate" the federal sentence. ${ }^{59}$

One nimble aspect of the Eleventh Circuit's approach is that it not only denies Ballard's dual sovereignty claim as "meritless," but it also characterizes the dual sovereignty concerns as actually favoring the right to impose the consecutive sentences at issue. ${ }^{60}$ According to the court, "each sovereign is entitled to have the defendant serve its respective sentence, and the defendant cannot choose the order of those sentences. The consecutive sentence imposed ... preserves that prerogative for both sovereigns, while a prospective concurrent sentence would not."

The Eighth Circuit and Tenth Circuit decisions on this issue parallel the Ballard court's interpretation of $\S 3584(\mathrm{a})$. Unlike the Eleventh Circuit's Ballard decision, however, the Eighth Circuit's decision in United States v. Mayotte, ${ }^{62}$ and the Tenth Circuit's decision in United States $v$. Wil-

53. Id

54. Id. at $\mathbf{I} 506$.

55. Id. (quoting U.S. Sentencing Guidelines Manual \$ 5GI.3(c) (1991)).

56. Id.

57. Id. at 1504.

58. Id. at $\mathbf{I} 506$.

59. Id. at 1509 (arguing that "[c]ontrary to Ballard's argument that the federaI sentence impaired the state court's sentencing ability to impose a concurrent sentence, $a$ concurrent sentence by the state court would encroach on the federal court's sentencing authority by, in effect, eliminating the federal sentence").

60. Id. at $\mathbf{I 5 1 0 .}$

61. Id.

62. 249 F.3d 797 (8th Cir. 2001). 
liams, ${ }^{63}$ lack any pointed treatment of dual sovereignty concerns. ${ }^{64}$ In Williams, the broad reading of the section's final sentence is essentially both the starting and ending point of the analysis, ${ }^{65}$ while the Mayotte opinion also provides a cursory mention of the Sentencing Guidelines and a confused summary of the minority position, but is otherwise merely a less thorough version of the Ballard statutory analysis. ${ }^{66}$

\section{The Minority's Restrictive Approach}

The circuits in the minority insist above all that $\$ 3584(\mathrm{a})$ must be interpreted in its entirety. The Ninth Circuit's opinion in United States $v$. Clayton is a clear indication of this philosophy. ${ }^{67}$ On November 3, 1989, Joseph Dean Clayton was sentenced to a twenty-four month federal prison term for making false statements in the acquisition of a firearm and possession of a firearm by a felon. The district court indicated that the sentence was to run "consecutive to any state sentence." 68 Three days later Clayton was sentenced to a seventeen-month prison term on state charges of second degree burglary and second degree robbery. The Washington state judge indicated that the sentence was to be served concurrently with the previously imposed federal sentence. ${ }^{69}$ Clayton appealed on the ground that the district court erred in directing that his federal sentence be consecutive to a state sentence that had not yet been imposed. ${ }^{70}$ Unlike the decisions of the majority, the Ninth Circuit's Clayton opinion focuses on the initial portions of $\$ 3584$ (a), stating that:

18 U.S.C. $\$ 3584$ (a) provides, in pertinent part, that "if a term of imprisonment is imposed on a defendant who is already subject to an undischarged term of imprisonment, the terms may run concurrently or consecutively." . . . However, the limiting language of section 3584(a), coupled with supporting legislative history, indicates that Congress did not vest federal courts with the author-

63. 46 F.3d 57 (10th Cir. 1995).

64. See infra Part H.B (detailing the Ballard court's dual sovereignty contentions in the context of the non-statutory ramifications posed by the consecutive sentences).

65. See supra note 36 (reproducing the Tenth Circuit's analysis in Williams).

66. See Mayotte, 249 F.3d at 799 (characterizing "the concerns discussed by the circuits holding the minority view" as "deferen[tial] to the Attorney General's authority under separation-of-powers principles, and to the state court's authority under comity principles"). The court's summary reflects the confusion that exists not only among the Circuits, but within them as well. The excerpt reflects secondary concerns addressed primarily in Romandine, but the Mayotte court's "summauy" in no way summarizes the minority position, which is grounded first and foremost in statutory analysis. See infra Part I1.C (detailing the Seventh Circuit's analysis in United States v. Romandine, 206 F.3d 731 (7th Cir. 2000) (Easterbrook, J.)).

67. 927 F.2d 491 (9th Cir. 1991).

68. Id. at 492 .

69. Id.

70. Id. 
ity to impose a federal sentence to run consecutive to a state sentence that has not yet been imposed. ${ }^{71}$

This approach is consistent with the Sixth Circuit's in Quintero:

To reach [the conclusion that the sentences should be disallowed], we rely primarily on the language of section 3584(a). Section 3584 (a) only authorizes district courts to impose concurrent or consecutive sentences if the court either imposes multiple terms of imprisonment on the defendant at the same time or imposes a sentence on a defendant who is "already subject" to an undischarged term of imprisonment. ${ }^{72}$

On this central issue of statutory interpretation, the Seventh Circuit is also in accord:

We join the circuits that answer "no," because $\$ 3584$ (a) allows the district judge to specify the sequence of service only when sentences are imposed at the same time, or the other sentence is "an undischarged term of imprisonment" to which the defendant is "already subject." 73

Finally, the consistency of the approach is illustrated by McCarthy $v$. Doe, where the Second Circuit conducted the exact same statutory inquiry even though it was deciding a slightly different issue:

The opening sentence of $\S 3584$ (a) establishes that this statute applies where multiple terms of imprisonment are imposed on a defendant at the same time, or where a term of imprisonment is imposed on a defendant who is already subject to an undischarged term of imprisonment. The presumptions established by the last two sentences of $\S 3584$ (a) must be read in light of this limiting language at the beginning of the section. . . .

This literal reading of the sentence is reinforced by common sense. The federal sentencing court would be expected to know about a sentence previously imposed. ${ }^{74}$

71. Id. (quoting I8 U.S.C. $\$ 3584(a)$ ).

72. United States v. Quintero, 157 F.3d 1038, 1039-40 (6th Cir. 1998) (quoting 18 U.S.C. $\$ 3584(\mathrm{a}))$.

73. Romandine v. United States, 206 F.3d 731, 738 (7th Cir. 2000) (Easterbrook, J.) (quoting 18 U.S.C. $\$ 3584(\mathrm{a})$ ).

74. McCarthy v. Doe, 146 F.3d 118, 121-22 (2d Cir. 1998). As indicated supra note 2, the Second Circuit's position on the question of whether or not federal courts may impose sentences consecutive to state sentences that have yet to be imposed may be officially discerned only through Salley v. United States, 786 F.2d 546 (2d Cir. 1986), which preceded the enactment of $\$ 3584(\mathrm{a})$.

The McCarlhy court explicitly indicated that the case did "not raise the issue of a sentencing court's authority to designate a federal sentence to run consecutively to a notyet-imposed state sentence." McCarthy, 146 F.3d at 121. However, the issue in McCarthywhether the Bureau of Prisons had the discretion to designate a state facility as a place of confinement for a federal sentence " $[w]$ here a sentencing court does not indicate whether a federal sentence should be served consecutively to or concurrently with a not-yetimposed state sentence"-called for similar statutory analysis. Id. at 119. So while the Second Circuit was prudent in deciding only the precise issue before the court, one may reasonably posit that based on the McCarthy panel's statutory interpretation, and its 
Statutory interpretation is so critical to the minority position that a cursory summary of their analysis could stop here and still be adequate. The narrower reading of $\$ 3584$ (a) precludes the need to address the sentencing factors in $\$ 3553(\mathrm{a})$ and thus precludes the need to address the Sentencing Guidelines. While the circuits in the majority must analyze these circumscriptions on judicial exercises of discretion, the circuits in the minority are not so required, because they conclude as a threshold matter that the sentences at issue fall completely outside the realm of discretion. ${ }^{75}$

Although their analysis could easily end with that determination, the circuits in the minority have nonetheless bolstered their statutory construction arguments with non-statutory policy considerations. Picking up on the dual sovereignty concerns voiced in its own circuit's Eastman decision, the Clayton court reiterated the apprehension that the controversial sentences would "preempt the right of the state to apply its own laws on sentencing for violation of state criminal laws."76 The Clayton court further indicated that on its view, "[s] uch potential difficulties arising from dual sovereignty are best avoided if neither sovereign binds the sentencing discretion of the other." 77 Finally, Clayton echoed the Eastman conclusion that the consecutive sentences at issue "infring[e] upon the rights of the defendant," 78 in that they deprive the defendant of the "right to have a state court consider whether a state sentence should run concurrently with his federal sentence," ${ }^{79}$ and that the sentences create "uncertainty and ambiguity which may in the future result in problems in calculation of service" of the defendant's sentence. ${ }^{81}$

interpretation of the applicable legislative history, the Second Circuit would likely sicle with the Sixth, Seventh, and Nintl circuits were the issue to come before the court.

In any event, a sound, if reductionist, summary of the Second Circuit position is as follows: Salley technically places the circuit in the majority on the precise question, but this designation is subject to the caveat that the case preceded the enactment of $\$ 3584(\mathrm{a})$; MeCarthy places the circuit firmly in the camp preferring the narrow reading of the statute; and Judge Newnan's Salley concurrence remains the seminal analysis favoring the nonstatutory arguments of the circuits in the minority.

75. See United States v. Quintero, 157 F.3d 1038, 1041 (6th Cir, 1998) (characterizing the Fifth Circuit, in Brown, as relying on "the district court's general discretion in choosing between imposing a consecutive or concurrent sentence"). The Quimtero court's one sentence response 10 the Fifth Circuit approach is indicative of the minority circuits' overall emphasis on the statute: "We do not believe that this general discretion can trump the express statutory conditions we have discussed." Id.

76. United States v. Chayton, 927 F.2d 491, 493 (9th Cir. 1991) (quoting United States v. Eastman, 758 F.2C1 1315, 1318 (9th Cir. 1985)).

77. Id.

78. Id.

79. 1d.

80. Id. (quoting Lastman, 758 F.2d al 1318). 
II. The Text of $\S 3584$ (a) and Principles of Dual Sovereignty Favor THE Minority's Restrictive Approach

\section{A. Statutory Analysis}

The narrower reading of $\S 3584$ (a) favored by the Second, Sixth, Seventh, and Ninth Circuits is the product of a judicially prudent approach and is more consistent with widely accepted methods of statutory interpretation. Indeed, the narrower reading is well-supported by at least three major approaches to statutory interpretation: an ordinary-meaning textualist approach, an approach using canons of statutory interpretation emphasizing dual sovereignty, and a purposive rubric utilizing legislative history to resolve statutory ambiguity.

1. Ordinary-Meaning Textualist Interpretation of $\$ 3584(a)$. — "The text is most often the starting point for interpretation, and textual arguments carry the greatest argumentative weight." ${ }^{1}$ According to the Tenth Circuit in Williams, a "plain meaning" reading of $\S 3584$ (a) reveals no language specifically "prohibiting a district court from ordering that a federal sentence be served consecutively to a state sentence that has not yet been imposed." ${ }^{2}$ This is only true if one does not read the closing portion of $\$ 3584$ (a) in the context of the entire section, which is a direct contravention of an ordinary meaning approach. Justice Scalia, among the most ardent of the textualists, has stated that "[w]ords, like syllables, acquire meaning not in isolation but within their context." 83 The same is true for individual sentences within a statutory provision such as $\$ 3584(\mathrm{a})$. An ordinary-meaning textual reading of the statute indicates that the final portion of $\S 3584$ (a) applies only to the circumstances indicated at the outset. Effectively, this means that the presumption that sentences will be consecutive "unless the court orders that the terms are to run concurrently" 84 applies to "multiple terms of imprisonment" 85 only if a term is to be imposed on a defendant "already subject to an undischarged term of imprisonment." 86 By parallel reasoning, the presumption that sentences will run concurrently applies to "multiple terms of imprisonment" 87 only if the terms are imposed "at the same time." $\$ 8$

81. William N. Eskridge, Jr. \& Philip P. Frickey, Statutory Interpretation as Practical Reasoning, 42 Stan. L. Rev. 321, 354 (1990).

82. United States v. Williams, 46 F.3d 57, 59 (10th Cir. 1995).

83. K Mart Corp. v. Cartier, Inc., 486 U.S. 281, 319 (1988) (Scalia, J., concurring in part and dissenting in part); see also NLRB v. Federbush Co., 121 F.2d 954, 957 (2d Cir. 1941) (L. Hand, J.) (noting that " $[\mathrm{w}]$ ords are not pebbles in alien juxtaposition; they have only a communal existence; and not only does the meaning of each interpenetrate the other, but all in their aggregate take their purport from the setting in which they are used").

84. 18 U.S.C. $\$ 3584$ (a) (2000).

85 . Id.

86. Id.

87. Id.

88. 1d. 
Phrased differently, the same statutory analysis proceeds as follows: ${ }^{89}$ (1) The statute begins by stating the two circumstances where the statutory section applies; (2) the last two sentences in the section contain two default presumptions, each of which clearly corresponds to one of the two situations described initially; (3) if the last sentence (or the second sentence in the case of sentences imposed at the same time) were an independent grant of authority to impose consecutive sentences in all cases where two sentences are imposed at different times, the first sentence would serve no purpose-it would be subsumed by the last; 90 and (4) "common sense" reinforces this reading because "the federal sentencing court would be expected to know about a sentence previously imposed." 91

One potential response to this argument would be to claim that the purpose of the statute's first sentence is to set up the exception for "an attempt and for another offense that was the sole objective of the attempt." 92 Such a reading reduces the first sentence to a simple default rule similar to those established in the final two sentences. The default rule would simply be that in the case of attempt, the judge lacks any discretion with respect to consecutive treatment. The rejoinder to this is that like the interpretation employed by the circuits in the majority, this argument fails to ascribe any significance to the provision's opening language. If Congress intended merely to establish three straightforward default rules it could have done so without the limiting language provided in the statute's first sentence. For example, the statute could have been written as follows:

Multiple terms of imprisonment may not run consecutively for an attempt and for another offense that was the sole objective of the attempt. Multiple terms of imprisonment imposed at the same time run concurrently unless the court orders or the statute mandates that the terms are to run consecutively. Multiple terms of imprisonment imposed at different times run consecu-

89. For ease of reference with respect to this statutory analysis, $\S 3584$ (a) provides: If multiple terms of imprisonment are imposed on a defendant at the same time, or if a term of imprisonment is imposed on a defendant who is already subject to an undischarged term of imprisonment, the terms may run concurrently or consecutively, except that the terms may not run consecutively for an attempt and for another offense that was the sole objective of the attempt. Multiple terms of imprisonment imposed at the same time run concurrently unless the court orders or the statute mandates that the terms are to run consecutively. Multiple terms of imprisonment imposed at different times run consecutively unless the court orders that the terms are to run concurrently.

Id.

90. Such a reading of the final sentence would conflict with the rule against surplusage. This traditional canon of interpretation reflects a "presumption that every statutory term adds something to a law's regulatory impact." William N. Eskridge, Jr. et al., Legislation and Statutory Interpretation 266 (2000).

91. McCarthy v. Doe, 146 F.3d 118, 122 (2d Cir. 1998).

92. 18 U.S.C. $\S 3584$ (a). 
tively unless the court orders that the terms are to run concurrently. ${ }^{93}$

Functionally, the draft above accomplishes everything that is accomplished by the actual statute under the majority's interpretation. The language in the actual statute's first sentence is thus surplusage unless it is interpreted to limit the circumstances to which the provision appliesnamely to those situations in which "multiple terms of imprisonment are imposed on a defendant at the same time, or [where] a term of imprisonment is imposed on a defendant who is already subject to an undischarged term of imprisonment." 94

Recall that a defendant, convicted in federal court, but not yet convicted on any state criminal charges, falls within the ambit of the sentences in controversy. Such a defendant is clearly not one upon whom multiple terms are being imposed at the same time. Nor is such a defendant "already subject to" 95 a second term of imprisonment. One would be hard pressed to argue in a criminal justice system founded on the presumption of innocence that defendants are "subject to a term of imprisonment" 96 prior to a conviction. ${ }^{97}$ As such, the circuits that interpret the final portion of $\S 3584$ (a) permissively do not make that argument, but choose not to address this limiting language despite its facially apparent location within the statute. ${ }^{98}$

Finally, reading this criminal statute restrictively is consistent with the rule of lenity. To the extent that one may reasonably find both the majority's permissive reading of the statute and the minority's restrictive reading to be plausible, "[ $\mathrm{t}]$ he [Supreme] Court has often stated that when there are two rational readings of a criminal statute, one harsher

93. The text accompanying this footnote is not that of $\S 3584$ (a), but is rather a hypothetical redrafting of $\$ 3584$ (a) that would delete, rather than merely render meaningless, the provision's opening language. To refer to the actual text of $\S 3584$ (a), see supra note 89 .

94. 18 U.S.C. $\$ 3584$ (a).

95. Id.

96. Id.

97. Clearly, a defendant charged but not convicted of a state offense who is incarcerated while awaiting resolution of the state charges is, to an extent, subject to an undischarged term of imprisonment. The sentences at issue, however, also apply to defendants not imprisoned prior to resolution of any state charges pending against them, and even to state charges that have not yet been brought against the defendant at all. See, e.g., United States v. Eastman, 758 F.2d 1315, 1317 (9th Cir. 1985) (stating that the District Court imposed a sentence that was "ordered" to "run consecutive to any sentence that the defendant receives from the State of California").

98. The majority's analytical omissions are particularly conspicuous given that the courts on both sides either implicitly or explicitly acknowledge that the inquiry into whether the sentences are allowable must begin with the statute. See, e.g., United States v. Brown, 920 F.2d 12I2, 1217 (5th Cir. I991) (reproducing $\$ 3584$ (a) almost in its entirety and citing the collective whole as authorizing courts to "consider subsequent sentences anticipated, but not yet imposed, in separate state court proceedings"); see also supra note 45 and accompanying text (criticizing the Brown analysis). 
than the other, [courts] are to choose the harsher only when Congress has spoken in clear and definite language."99

The statutory interpretation favored by the Romandine, Quintero, $M c^{-}$ Carthy, and Clayton courts is more persuasive both because the analysis is compelling and because it is analysis. Textualism requires that in interpreting a statute, the "interpreter should approach the statutory text as a reasonably intelligent reader would and give the text its most commonsensical reading." 100 Applying this approach to $\$ 3584$ (a) in its entirety, the more plausible reading of the statute is the narrower reading preferred by the circuits in the minority. ${ }^{101}$

2. Interpreting \$3584(a) in Light of Dual Sovereignty Concerms. - In Chisom v. Roemer, Justice Scalia stated that judges should "first, find the ordinary meaning of the language in its textual context; and second, using established canons of construction, ask whether there is any clear indication that some permissible meaning other than the ordinary one applies." 102 While the most persuasive argument in favor of the ininority's restrictive approach is the ordinary meaning analysis detailed above, the conclusion produced by that analysis is reinforced by traditional canons of statutory interpretation. Given the dual sovereignty concerns inherent in the sentences at issue, the canon of construction most applicable to the inquiry is the "plain statement rule."

According to the Supreme Court, "if Congress intends to alter the 'usual constitutional balance between the States and the Federal Government,' it must make its intention to do so 'unmistakably clear in the language of the statute." 103 Intrusions on state authority to carry out state

99. McNally v. United States, 483 U.S. 350, 359-60 (1987) (citations omitted).

100. Eskriclge \& Frickey, supra note 81 , at 355.

101. Modem legislation frequently requires reference to multiple sections of a statute to determine the contextual meaning of individual provisions. As then-Circuit Judge Keuneth Starr wrote:

[E]specially in the post-New Deal model of highly detailed statutes, the statute reader may fruitfully draw on the entirety of the statute, studying the whole rather than the solitary part (or parts) put before the court by the specific case at hand. Answers may emerge from a study of the whole that might not be suggested by a narrowly focused parsing of a solitary provision in a complex statute.

Kenneth W. Starr, Of Forests and Trees: Structuralism in the Interpretation of Statutes, $\mathbf{5 6}$ Geo. Wash. L. Rev. 703, 708 (1988). While Judge Starr's reasoning reflects the need to harmonize multiple sections of complex statutes, it applies a fortiori to the analysis of individual sentences within a single statutory paragraph.

102. 501 U.S. 380, 404 (1991) (Scalia, J., dissenting) (emphasis added).

103. Will v. Mich. Dep't of State Police, 491 U.S. 58, 65 (1989) (quoting Atascadero State Hosp. v. Scanlon, 473 U.S. 234, 242 (1985)). The Will Court concluded that "Congress should make its intention 'clear and manifest' if it intends to pre-empt the historic powers of the States." Id. at 65 (quoting Rice v. Santa Fe Elevator Corp., 331 U.S. 218, $230(1947)$ ). fn their book Legislation and Statutory Interpretation, William N. Eskridge, Jr., Phillip P. Frickey, and Elizabeth Carrett note that "[t]he Supreme Cout has long attempted to use canous to ameliorate the tension between the Supremacy Clause, which provides that federal statutes are the 'law of the land' and trump state law, and the underlying principles of federalism reflected in Article I and the Tenth Amendment." 
criminal law clearly alter the usual constitutional balance, ${ }^{104}$ and, in such circumstances "it is incumbent upon the federal courts to be certain of Congress' intent before finding that federal law overrides" the federalstate balance. ${ }^{105}$

The Supreme Court's recent emphasis on protecting traditional areas of state sovereignty is particularly relevant to the sentences that are the subject of this Note. In Gregory v. Ashcroft, the Court held that the federal Age Discrimination in Employment Act did not apply to appointed state judges. ${ }^{106}$ The Court reasoned that the plain statement rule indicates that in order to find a congressional attempt to regulate a "core" state function, the Court "must be absolutely certain that Congress intended such an [attempt]." 107 Applying this canon of interpretation to the present discussion, it is apparent that not only is there a lack of absolute certainty that Congress intended $\$ 3584(\mathrm{a})$ to authorize the sentences in controversy, but that whatever ambiguity does exist in the statute militates in favor of the opposite conclusion. Indeed, "to give the state-displacing weight of federal law to mere congressional ambiguity would evade the very procedure for lawmaking on which Garcia relied to protect states' interests." 108 As in Gregory, application of the plain statement rule to the statutory analysis of $\$ 3584$ (a) is the judicially prudent course at least in part because its very application "may avoid a potential

Eskridge, Jr. et al., supra note 90 at 354-55. The authors note further that "[w]hen a federal law and a state law are arguably inconsistent, the Court 'start[s] with the assumption that the historic police powers of the States were not to be superseded by the Federal Act unless that was the clear and manifest purpose of Congress." Id. at 355 (quoting Santa Fe Elevator Corp., 331 U.S. at 230).

104. In Pennsylvania Department of Corrections v. Yeskey, 524 U.S. 206, 209 (1998), the Supreme Court "[a]ssum[ed], without deciding, that the plain-statement rule" applied to the administration of state prisons. Juslice Scalia, writing for a unanimous Court, noted that: "One of the primary functions of government . . . is the preservation of societal order through enforcement of the criminal law, and the maintenance of penal institutions is an essential part of that lask . . . It is difficult to imagine an activity in which a State has a stronger interest." Id. (citations omitted). The Court determined in Yeskey, however, that the Americans with Disabilities Act satisfied the plain-statement rule because it "plainly cover[ed] state institutions without any exception." 1d. In United States v. Lopez, the Supreme Court noted that: "Under our federal system, the 'States possess primary atthority for defining and enforcing the criminal law." 514 U.S. 549,561 n.3 (1995) (quoting Brecht v. Abrahamson, 507 U.S. 619, 635 (1993)). The preceding statement is even more patently applicable when the acts of definition and enforcement at issue pertain to a state judge defining a defendant's slate sentence in order to enforce a stale criminal law. Thus, this Note argues that in analyzing whether Congress has atrhorized federal district court judges to issue sentences that preclude subsequent state judges from issuing concurrent sentences to the same defendants on state charges, the relevant statutes should be interpreted in light of the plain-statement rule.

105. Alascadero, 473 U.S. at 243.

106. 501 U.S. 452,473 (1991).

107. 1d. at 464 (citing Garcia v. San Antonio Metro. Transit Auth., 469 U.S. 528 (1985)).

108. Id. (quoting Laurence H. Tribe, American Constitutional law $\$ 6-25$, at 480 (2d ed. 1988) (internal quotation marks omitted)). 
constitutional problem." 109 Narrowly construing statutory ambiguity in favor of avoiding constitutional questions is "[p]erhaps the most important of the constitutionally based canons." 11 " The restrictive approach avoids any federal intrusion into the administration of state criminal law and is thus consistent both with the Court's plain statement rule and the longstanding canon that courts should construe statutory ambiguity so as to avoid constitutional controversy.

3. The Legislative History of $\$ 3584(a)$. - The legislative history of $\$ 3584$ (a) supports the narrower interpretation both through what it says, and through its silence with regard to state sentences that have yet to be imposed. As a matter of common sense, it seems unlikely that Congress would affirmatively circumscribe the sentencing power of state judges over violations of state law, without any indication of such an intention either in the statute itself or in the legislative history.

While the circuits in the majority ignore the legislative history, the minority's legislative history analysis is based on a Senate Report that "specifically notes that $\S 3584(\mathrm{a})$ 's presumption that multiple terms of imprisonment imposed at different times run consecutively 'changes the law that now applies to a person sentenced for a Federal offense who is already serving a term of imprisonment for a State offense." 111 The discussions of consecutive sentences in the Senate Report refer variously to: "a term of imprisonment imposed on a person already serving a prison term"; ${ }^{112}$ to sentences "imposed while the defendant is serving another one";113 and, as noted above, to "a person sentenced for a Federal offense who is already serving a term of imprisonment for a State offense." 14 The Ninth Circuit acknowledged that the crucial phrase "already subject to" might "conceivably be interpreted broadly to encompass those defendants found guilty of, but not yet sentenced for, a state offense."115 However, like both the Second and Sixth Circuits, the Ninth Circuit concluded from the legislative history that "Congress contemplated only that federal sentencing be consecutive to state convictions for which the defendant was already sentenced."116

109. Id.

110. Bradford C. Mank, Textualism's Selective Canons of Statutory Consuruction: Reinvigorating Individual Liberties, Legislative Authority, and Deference to Executive Agencies, 86 Ky. L.J. 527, 571 (1998); see also Int'l Ass'n of Machinists v. Street, 367 U.S. 740, 749-50 (1961) (noting that in the face of constitutionally troubling interpretations "it is a cardinal principle that this Court will first ascertain whether a construction of the statute is fairly possible by which the question may be avoided" (quoting Crowell v. Benson, 285 U.S. 22, 62 (1932))).

111. McCarthy v. Doe, 146 F.3d 118, 122 (2d Cir. 1998) (quoting S. Rep. No. 98-225, at 127 (1983), reprinted in 1984 U.S.C.C.A.N. 3182, 3310).

112. S. Rep. No. 98-225, at 127, reprinted in 1984 U.S.C.C.A.N. $3182,3310$.

113. Id. (emphasis added).

114. Id. (emphasis added).

115. United States v. Clayton, 927 F.2d 491, 492. (9th Cir. 1991).

116. Id. 
Standing alone, the little relevant legislative history that exists is clearly not persuasive, and is, for that matter, only of marginal value even when combined with the other means of analysis more directly applicable to the question at issue. Still, though sparing and inconclusive, that history is consistent with the restrictive approach to the statute. This is especially true in light of the fact that the statute was enacted against a backdrop including the most basic "common sense" intuition alluded to in the Second Circuit's McCarthy decision, namely that a federal judge would be expected to know about previously imposed state sentences, but by definition, would not be expected to know about those not yet in existence. ${ }^{117}$

\section{B. Non-statutory Considerations}

The circuits on each side of this split make arguments based on dual sovereignty concerns. Of the courts favoring the sentences at issue, the Ballard court is the most strident in its contention that dual sovereignty concerns militate in favor of allowing federal courts to impose sentences consecutive to state sentences that have yet to be imposed. The Ballard court's argument warrants serious consideration. In seeking to "fulfill the punishment and deterrence purposes of incarceration," the Ballard court found that the controversial sentences were not only acceptable but, under the circumstances of that case, necessary, and concluded that through the sentences, "[d]ual sovereignty, manifested in the sentencing authority and sentence of each sovereign, [is] respected." 18

Conversely, Eastman and Clayton emphasize state sovereignty and a state's discretion to execute its own criminal sentences in the manner that it deems appropriate. One of the Clayton court's most salient nonstatutory assertions is the notion that the "potential difficulties arising from dual sovereignty are best avoided if neither sovereign binds the sentencing discretion of the other." 19 For example, at no point during the discussion has either side argued that a state is able to sentence its criminal defendants to sentences that are required to be consecutive to federal sentences that have yet to be imposed. This would be a clear intrusion into the federal government's sovereign power to impose the sentences it deems necessary for the proper administration of federal law. ${ }^{120}$

117. See supra note 74 and accompanying text (noting the McCarthy court's comment that the restrictive reading of the statute "is reinforced by common sense" since "[ $t]$ he federal sentencing court would be expected to know about a sentence previously imposed," McCarthy v. Doe, 146 F.3d 118, 122 (2d Cir. 1998) (emphasis added)).

118. United States v. Ballard, 6 F.3d 1502, 1510 (11th Cir: 1993); see supra notes 47-48 and accompanying text (describing the unique facts in Ballard).

119. Clayton, 927 F.2d at 493.

120. See, e.g., Hawley v. United States, 898 F.2d 1513, 1514 (11th Cir. 1990) (holding that states may not bind federal courts by directing that a state sentence is to run concurrently with a yet-to-be-imposed federal sentence); Pinaud v. James, 851 F.2d 27, 30 (2d Cir. 1988) (same). Though the question of law as to the validity of such sentences is both settled and beyond the scope of this Note, it bears mentioning that such sentences, if 
Claims that disallowing the sentences at issue would result in the relative demise of federal sentencing powers are greatly exaggerated. If a federal district court sentences a criminal defendant to one year in prison, there is no way for any authority outside the federal government to reduce that sentence. Disregarding federal parole and early-release provisions, the defendant will serve no less than the one year originally sentenced. If a subsequent state judge chooses, as authorized by the pertinent state's laws, to sentence that same defendant on a state conviction to a term of imprisonment that is to be concurrent in whole or in part with the federal sentence, this action does not in any way change the federal sentence for the federal crime. 1 is a highly lenient administration of state criminal law, but lenient administration of state law is a matter of state prerogative. Consider that the federal government may not prevent states from sentencing state criminals to terms of no imprisonment whatsoever. Where then is the justification for preventing states from crediting convicts for time served while they are confined in nonstate facilities? If the boundaries of federalism are even remotely substantial, arguing in favor of such a justification is a formidable task indeed.

issued, would arguably run counter to the Supremacy Clause of the Constitution. U.S. Const. art. $\mathrm{Vl}, \mathrm{cl} .2$.

One may detect a degree of dissonance between one aspect of the Note's thesis-that a federal district court should not be able to bind the sentencing discretion of its yet to act state counterpart-and the exceptions to the Anti-lnjunction Act, 28 U.S.C. $\$ 2283$ (2000). The Act provides that: "A court of the United States may not grant an injunction to stay proceedings in a State court except as expressly authorized by Act of Congress, or where necessary in aid of its jurisdiction, or to protect or effectuate its judgments." Id. The exceptions allow federal courts to stay proceedings in a state court in certain narrow circumstances. While injunctions per se are not applicable to the question addressed in this Note, the reasons the Supreme Court has given for construing the exceptions to the Act narrowly parallel the fundamental reasoning favoring the restrictive approach to the controversial federal sentences. In Atlantic Coast Line R.R. v. Brotherhood of Locomotive Engineers, 398 U.S. 281, 287 (1970), the Court, interpreting the Anti-lnjunction Act, declared that "since the statutory prohibition against such injunctions in part rests on the fundamental constitutional independence of the States and their courts, the exceptions should not be enlarged by loose statutory construction." Concededly, that language may be contrasted with the Court's decision in Mitchum v. Foster, 407 U.S. 225 (1972), which found that 42 U.S.C. $\$ 1983$ authorized injunctions even though the provision does not explicitly mention injunctions of state court proceedings. In Mitchum, however, the Court unanimously found it "evident that Congress clearly conceived that it was altering the relationship between the States and the Nation with respect to the protection of federally created rights" and that in fact the "very purpose of $\$ 1983$ was to interpose the federal courts between the States and the people as guardians of the people's federal rights." Id. at 242. Not only is such an evident and sweeping purpose not to be found in 18 U.S.C. $\$ 3584(\mathrm{a})$, but moreover, one must bear in mind that rather than applying to parallel proceedings as the Anti-lnjunction Act does, the controversial sentences that are the subject of this Note reach completely separate state and federal crimes that do not even necessarily arise from related transactions or occurrences. For a thorough examination of the jurisprudence surrounding the Anti-Injunction Act, see Richard H. Fallon et al., Hart and Wechsler's The Federal Courts and the Federal System 1148-69 (5th ed. 2003). 
Consider hypothetically that if a state judge is faced with a mandatory minimum sentence that she deems overly harsh in light of the particular facts or circumstances surrounding a defendant or case, she may effectively mitigate this severity by imposing a sentence concurrent with the defendant's existing federal sentence. She is certainly not required to do so, and is only allowed to do so if specifically authorized by state law, but the federal government preventing the state prerogative is hardly, as claimed in Ballard, respecting the law of each sovereign. ${ }^{121}$

By definition, a subsequent state court is better positioned than a preceding federal court to analyze the full panoply of circumstances surrounding a defendant at the time of sentencing. This is one of the central concerns raised by Judge Newman in his Salley concurrence, ${ }^{122}$ and yet for all the emphasis the circuits in the majority place on judicial discretion, they neglect to address just which members of the judiciary are best situated to exercise that discretion.

The scenario that played out in Ballard provides a marginally compelling policy argument for the sentences at issue. ${ }^{123}$ The particular facts of that case surely represent a peculiar extreme, but it must be granted to the majority that, for Timothy Ballard, the potential of being allowed to serve a concurrent state sentence in a federal facility not only failed to deter him from committing a crime but actually enticed him to do so. Ballard's actions were as risky as they were extraordinary. ${ }^{124}$ Lest it appear as though this "incentive" would be attractive to convicts in general, consider that at the subsequent state sentencing proceeding Ballard's actions would likely militate strongly in favor of a consecutive sentencemeaning those with Ballard's disposition would not only fail in their attempts at manipulation, but would also increase the length of their cumulative terms of imprisonment. Also, depending on the expected state sentence, the federal judge could compensate by giving a very long sentence

121. See Ballard, 6 F.3d at 1510 (contending that "each sovereign is entitled to have the defendant serve its respective sentence" and that the consecutive sentence "preserves that prerogative for both sovereigns, while a prospective concurrent sentence would not").

122. Salley v. United States, 786 F.2d 546, 548 (2d Cir. 1986) (Newman, J., concurring) (noting that the "strong medicine" of a consecutive sentence should only be used "after awareness of a sentence already imposed so that the punitive effect of the consecutive sentence is carefully considered at the time of its imposition").

123. See supra notes $47-48$ and accompanying text.

124. The Ballard court strained to distinguish itself from the cases that had ruled on the issue previously based on its factual idiosyncrasies. See 6 F.3d at 1507 ("This appeal is distinctive, both within our circuit and nationwide ... as [Ballard] deliberately and admittedly committed his federal offense with the intention of being sentenced first by the federal court so that his prospective state sentence would be served concurrently in federal prison, thereby avoiding state incarceration.").

Ironically, contemporary circuits in the minority may thus easily distinguish Ballardthe most thorough and persuasive case among those taking the majority view-on factual grounds. See, e.g., United States v. Quintero, 157 F.3d 1038, 1041 (6th Cir. 1998) ("We distinguish Ballard based on the Ballard court's own repeated stress on the 'unique' facts of the case ...."). 
for the federal crime, though this is more difficult in a Guidelines regime. Is it possible that a few rare individuals might attempt this? 1ndisputably, yes, but in light of the procedural safeguards already in place and the potential penalties if such an attempt fails, this minute risk does not justify intruding on state sovereignty and defendants' rights. Like many sound regulatory policies that lead to isolated attempts at evasion, the policy attributes of disallowing the sentences in controversy-states' rights, defendants' rights, and, at least for the time being, adherence to applicable statutes and legislative intent-more than outweigh the policy attributes of the majority's permissive approach.

\section{Addressing Romandine's "Illusory" Contention}

The Seventh Circuit, in Romandine v. United States, agreed with the circuits opposed to the consecutive sentences at issue as to the central question of statutory interpretation, ${ }^{125}$ but Judge Easterbrook's decision ultimately concluded that the conflict among the circuits "is illusory" and, moreover, that "the answer [to whether a district judge may require that a defendant's federal sentence be consecutive to a yet-to-be imposed state sentence] does not matter." 126

The Romandine court based this aspect of its analysis primarily on the final sentence of $\S 3584(\mathrm{a})$, which the court claimed "makes the federal sentence presumptively consecutive in all unprovided-for cases, and the effective decision then is made by the Attorney General (or the state judge) rather than the federal judge." 127 Judge Easterbrook's conclusion is essentially that even if one concedes (though the Seventh Circuit expressly did not) that district court judges have the power to impose the consecutive sentences at issue, the power will not be of consequence. This is because the Attorney General will maintain the post-sentence discretion to refuse to accept the defendant into federal custody until the defendant has completed her state sentence (thus effecting consecutive treatment) or to declare the state prison to be an official detention facility for purposes of the particular defendant (thus effecting concurrent treatment). Meanwhile, the state judge will have the options of: (I) explicitly ordering concurrent treatment in the hope that the federal government will simply allow the prisoner to first serve time in the federal facility despite the pre-existing federal sentence; (2) discounting the state

125. 206 F.3d 731, 738 (7th Cir. 2000) (Easterbrook, J.) (noting the split among the circuits as to whether the consecutive sentences at issue are allowed by $\S 3584$ (a) and stating that: "We join the circuits that answer 'no,' because $\$ 3584$ (a) allows the district judge to specify the sequence of service only when sentences are imposed at the same time, or the other sentence is 'an undischarged term of imprisonment' to which the defendant is "already subject"" (quoting 18 U.S.C. $\$ 3584(a))$ ).

126. ld.

127. Id. 
sentence imposed; or (3) releasing the defendant from state custody early in anticipation of an undischarged federal sentence. ${ }^{128}$

It is inaccurate to characterize the split as illusory as the split is potentially quite important to the defendants to whom it applies. The argument that the split is "illusory" assumes that state judges not only have the discretion to contradict federal judicial orders pertaining specifically to their own state sentences, but that they will actually be willing to do so on a regular basis, despite several federal appellate court rulings upholding the consecutive sentences at issue.

It is a mischaracterization to claim the conflict is illusory solely because state judges might justifiably disregard the federal rulings-especially if the conflict itself makes such maverick action even marginally less likely. The options to discount anticipated federal time or to release prisoners early are options only to the extent that state judges are willing to engage in a protracted game of sentencing Ping-Pong. From both the point of view of the defendant and of a state judge wishing concurrent treatment, the preference for being able to direct a concurrent state sentence without the need for such a game is hardly illusory. Note also that options two and three described above are of little avail where the defendant is facing a state mandatory minimum sentence. It is thus incontrovertible that at least in some marginal cases defendants will face increased prison time due in significant part to the controversial sentences. "[I]llusory" that is not.

As for the inverse scenario, consider that the Attorney General retains the discretion to declare a state detention facility to be a place of federal confinement but is unlikely to exercise this "lenient" act of authority in light of a federal judicial order specifically prohibiting a federal

128. The mechanics that Judge Easterbrook envisioned proceed as follows:

The next judge in line may make service concurrent in practical effect. For example, the state judge could [give the defendant] a discount ... on account of his undischarged sentence. Likewise the Attorney General could make the federal sentence run concurrently by designating the state prison as a place of federal confinement, so that the clock would start to tick on the federal sentence. ... All the Attorney General has to do is designate the state prison as the "official detention facility at which the sentence is to be served." By refusing to make this designation, and by instead lodging a detainer with state officials, the Attorney General can ensure consecutive service (although the Attorney General could not prevent the state from releasing its prisoner early because of the state's anticipation that federal time lay ahead).

Id. (quoting 18 U.S.C. $\$ 3585(a)$ ); see also, e.g., Del Guzzi v. United States, 980 F.2d 1269, 1272-73 (9th Cir. 1992) (Norris, J., concurring). There Judge William Norris explained: Federal prison officials are under no obligation to, and may well refuse to, follow the recommendation of state sentencing judges that a prisoner be transported to a federal facility. Moreover, concurrent sentences imposed by state judges are nothing more than recommendations to federal officials. Those officials remain free to turn those concurrent sentences into consecutive sentences by refusing to accept the state prisoner until the completion of the state sentence and refusing to credit the time the prisoner spent in state custody.

Id. 
sentence from being served concurrently with a then-future state sentence. This improbability is particularly pronounced because in federal criminal trials it is the Justice Department's United States Attorneysunder the purview of the Attorney General-who seek such sentences in the first place. Conceivably, this rejoinder might not hold true in the instance of a change of administration, but far more than such a contrived scenario is required to justifiably claim that the split is "illusory."

Even if the Attorney General feels no constraint, it affects the defendant if the state judge can direct a concurrent sentence, because this gives the defendant two bites at the apple instead of one. Conversely, if the federal judge can direct a consecutive sentence, the fact that the Attorney General may be able to undo that is not much help if the Attorney General is unsympathetic to defendants, or, as is far more likely, is unaware of the circumstances surrounding a particular defendant. This is analogous to saying the sentence does not matter because the President can pardon the defendant; he can indeed, but the defendant is better off having two shots at leniency than one.

The controversy surely matters to defendants whose state sentences are affected by federal judges who have no ability to consider the full spectrum of sentencing factors that a second-in-time state judge may take into account. Moreover, the Supreme Court's recent jurisprudence indicates that intrusions into "core" state functions are indeed of significant constitutional import. Finally, it is important to bear in mind that this entire discussion arises in Romandine only after the Seventh Circuit decided in favor of the narrow interpretation of $\$ 3584(\mathrm{a})$, and that even if one finds Judge Easterbrook's argument to be persuasive, it plainly was not controlling even for him. ${ }^{129}$

\section{CONCLusion}

The opening sentences of $\$ 3584$ (a) lay out the statute's scope of application. Federal sentences imposed with the requirement that they are to be served consecutively to state sentences that have not yet been imposed are beyond that scope. This statutory argument holds up when subjected to textualism, to approaches employing traditional canons of interpretation, to considerations of federal-state comity, and to approaches utilizing legislative history for interpretive guidance.

Ambiguities perceived in the statutory framework should be interpreted so as to protect defendants' rights and the rights of the states in which the defendants are found. Until either the Supreme Court or Congress affirmatively indicates otherwise, federal district court judges should not be permitted to impose sentences that are required to be consecutive to state sentences that have yet to be imposed.

129. Romandine, 206 F.3d at 738. 